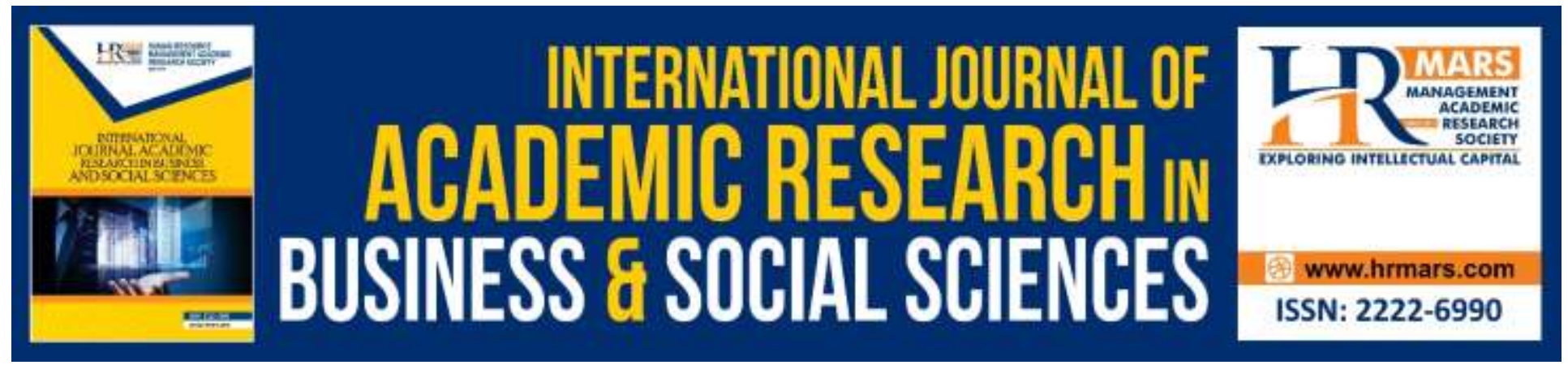

\title{
Conceptual Framework of Teachers' Competence in Teaching and Learning of Fine Motor Skills to Students with Special Education Needs (Learning Disabilities)
}

Farizan Che Musa, Noor Aini Ahmad

To Link this Article: http://dx.doi.org/10.6007/IJARBSS/v9-i11/6646

DOI: 10.6007/IJARBSS/v9-i11/6646

Received: 15 October 2019, Revised: 30 October 2019, Accepted: 07 November 2019

Published Online: 29 November 2019

In-Text Citation: (Musa \& Ahmad, 2019)

To Cite this Article: Musa, F. C., \& Ahmad, N. A. (2019). Conceptual Framework of Teachers' Competence in Teaching and Learning of Fine Motor Skills to Students with Special Education Needs (Learning Disabilities). International Journal of Academic Research in Business and Social Sciences, 9(11), 1180-1186.

Copyright: (C) 2019 The Author(s)

Published by Human Resource Management Academic Research Society (www.hrmars.com)

This article is published under the Creative Commons Attribution (CC BY 4.0) license. Anyone may reproduce, distribute, translate and create derivative works of this article (for both commercial and non-commercial purposes), subject to full attribution to the original publication and authors. The full terms of this license may be seen at: $\underline{\text { http://creativecommons.org/licences/by/4.0/legalcode }}$

Vol. 9, No. 11, 2019, Pg. 1180 - 1186

Full Terms \& Conditions of access and use can be found at http://hrmars.com/index.php/pages/detail/publication-ethics 


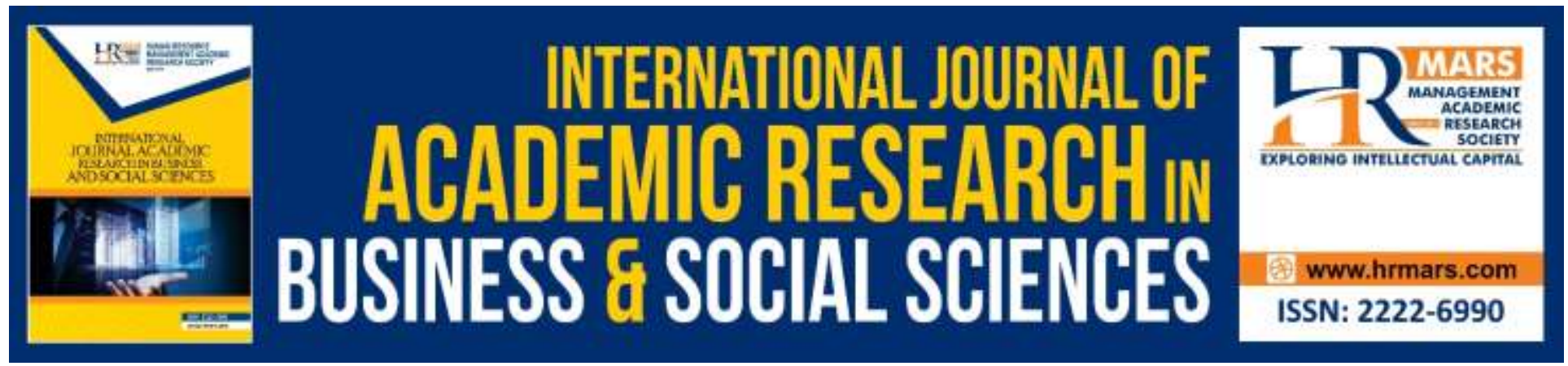

\title{
Conceptual Framework of Teachers' Competence in Teaching and Learning of Fine Motor Skills to Students with Special Education Needs (Learning Disabilities)
}

\author{
Farizan Che Musa, Noor Aini Ahmad \\ Department of Special Education, Faculty of Human Development, Universiti Pendidikan Sultan \\ Idris, Malaysia.
}

\begin{abstract}
Fine motor skill is the basic component of motor skills development. The skill will affect not only one's capability in academics but also the ability in performing daily tasks, if early interventions are not done. It is imperative that teachers are aware of the importance of the fine motor skill. Awareness is should then be followed with formal knowledge development or the teachers' initiatives in gaining knowledge and ensued by the teachers' ingenuity and creativity in developing avtivities on par with students' abilities and capabilities. The Iceberg Competency Model by Spencer \& Spencer (1993) is used as the basis to develop the concepual framework in this study. The conceptual framework is focusing on two layers - the visible layer which consists of knowledge and skills, and the hidden layer layer which consists of awareness. By combining awareness, knowledge and skills, a conceptual framework is designed to develop and increase teachers' professionalism in applying and practicing fine motor skill component in teaching and learning of students with special education needs (learning disabilities).
\end{abstract}

\section{Introduction}

Special education in Malaysia is a continuous effort to create individuals that are skilful, oriented, capable, faithful, independent, able to plan and manage daily living, and are aware of selfpotential as balanced and productive individuals and members of the society in line with the National Educational Philosophy. The National Primary School Special Education Standard Curriculum for Learning Disabilities (KSSRPK-LD) is developed in congruent with the National Educational Philosophy based on the principles of integrated approach, holistic individual development, equal educational opportunity and quality for all students and lifelong learning. 
KSSRPK-LD is all-inclusive in nature, not too academic and non-burdening to students in accordance to the Second Core of the National Educational Development Master Plan.

The developmental delay of motor skills will have a two-year gap in comparison with the delays of perception-visual, motor coordination and visual-motor integration (Pieters, Desoete, Roeyers, Vandderswalmen \& Waelvelde, 2012). Fine motor skill involves smaller muscles like the hands and fingers in activities such as eating with cutleries, hand drawing, cutting with scissors and writing (Kim, Carlson, Curby \& Winsler, 2016).

Knowledge, skill, emotion, behaviour, and values are conscious and sub-conscious dimensions that influence how teachers observe, evaluate, make decisions and react in a classroom interaction (Gomez, Nunez, Gomez \& Trapero, 2015). Teachers' development is influenced by visible and hidden awareness and need to be nurtured in multiple ways (Hedgcock \& Lee, 2017).

Knowledge is essential in improving teaching and learning for future generations and will always be part of research in education (Munthe \& Rogne, 2015). Teachers' learning is fostered via developed knowledge (Dudley, 2013). Acquiring knowledge, using obtained knowledge, generate new knowledge, knowledge sharing and contribute new knowledge are the strategies to the whole process of teachers' self-learning phase (Persico, Milligan \& Littlejohn, 2015).

Improving teaching skill is important in increasing abilities and motivation and is interrelated to teachers' experience in handling problems arising in classrooms (Saeedeh, Akbar, Habib \& Ali, 2015). Teachers have active-roles to teach, understand students' traits and performance and plan teaching methods (Katkat, 2014).

\section{Literature Review}

The literature review in this study focuses on fine motor skill of students with special education needs (learning disabilities), teachers' awareness, teachers' knowledge and skills in teaching and learning of fine motor skill to students with special education needs (learning disabilities).

\section{Fine Motor Skill of Students with Special Education Needs (Learning Disabilities)}

The early introduction and evaluation for children with special education needs (learning disabilities) are imperative to ensure that the children have the chance to adapt in social environment in the future (Terziev, 2014). Early detection and intervention are important to enable preventive measures are taken at early school stage (Reimer, Cox, Boonstra \& Sanden, 2015).

Teachers must focus on pencil-gripping technique while writing to have a better prevention program planning and to provide feedback to educational curriculum planner in improving curriculum development (Lim, Hanafi \& Mokhtar, 2012). Hand and eye coordination inefficiency can be detected when students are not holding pencils properly (Rasid, 2011).

Integrated learning allows students with special education needs to obtain basic skills to perform daily tasks and interact in social activities, together with students from mainstream classes (Barnaa, Dobrota \& Drague, 2013). Coordination development disorder is a serious 
INTERNATIONAL JOURNAL OF ACADEMIC RESEARCH IN BUSINESS AND SOCIAL SCIENCES

Vol. 9, No. 11, November, 2019, E-ISSN: 2222-6990 @ 2019 HRMARS

impairment that would have adverse effects on educational and daily life performances (Higashionna, Iwanaga, Tokunaga, Nakai, Tanaka, Nakane \& Tanaka, 2017).

\section{Teachers' Skills}

Comparative data analysis shows that there is no significant difference between new or unprofessional teachers and professional teachers in applying teaching techniques in different sizes of classroom (Azizinezhad, Nashemi \& Darvishi, 2013). Innovative teaching methods by younger teachers will allow matured teachers to observe new teaching techniques and increase the knowledge in contemporary teaching methods (Geeraerts, Vanhoof \& Bossche, 2016).

Developing the understanding towards effective teaching psychological profile will aid in the selection, training and professional development of both new and experienced teachers (Grosemans, Boon, Verclairen, Dochy \& Kyndt, 2015).

\section{Teachers' Knowledge}

Policies underlying teachers' training and preparations are involving two aspects which are training preparations for special education teachers in pedagogical knowledge and collaborative training designs (Bekirogullari, Soyturk \& Gulsen, 2011). The development and implementation of teachers' training preparations need to involve various interesting methods to manage students' behaviour in order to maintain the professional strength and expertise of education (Pellegrini, Weiss \& Regan, 2015).

Teachers' learning is fostered via developed knowledge (Dudley, 2013). Experienced teachers are aiding in realization of the importance of pedagogical knowledge in classroom management (Nabi \& Monireh, 2013).

\section{Teachers' Awareness}

Awareness in formative evaluation will help teachers to identify students' disability in learning (Yan \& Cheng, 2015). Self-reflection practices will not only improve teachers' pedagogical knowledge, self-awareness and self-perception, but it is also a form of sustainable professional development (Sanchez \& Borg, 2014).

The quality of teaching is directly related to the teachers' emotion of excitement and fulfilment as well as the student-teacher relationship (Serdenciuc, 2015). Teachers will require ample time to learn and execute classroom strategies (Kapadia, 2014).

\section{Conceptual Framework}

Teachers' competency is concluded based on literatures regarding teachers' awareness, knowledge and skills. Therefore a conceptual framework is developed in this study based on a framework model by Spencer \& Spencer (1993); the Iceberg Competency model. The model defines a person's inner competency and the relationships of performance effectiveness in a job situation.

According to the model, competency is divided into two components - visible and hidden. On above the water level is visible competency; which consists of, technically, knowledge and 
skills. Whereas at below the water level is the hidden competency; which consists of motive, selfattribute and self-concept (behaviour, values and will).

Knowledge and skills are fundamental for teachers to execute teaching and learning exercises. Knowledge is a mastery of obtained information. In the context of this study, knowledge comprises of pedagogical proficiency, curriculum comprehension and aimed objectives. Skill is referred to the teachers' ability in a classroom and in handling teaching and learning process. Knowledge and skills are closely interrelated.

Personal attributes and values are difficult to be developed, as they are dependant towards environmental influence as well as self-will. Self-concept (behaviour, values and will), self-attribute and motivation mentioned in the model are part of the hidden competency component. In the context of this study, teachers' awareness; which is a hidden attribute is observed. Awareness is a component of self-attribute which is a permanent and stable characteristic in a person and it is part of behaviour; which is derived from values and faith of the self-concept component. The combination of self-attribute and behaviour will lead to the awareness in fulfilling responsibilities and the effort to continuously improve self-will together with professionalism of teachers.

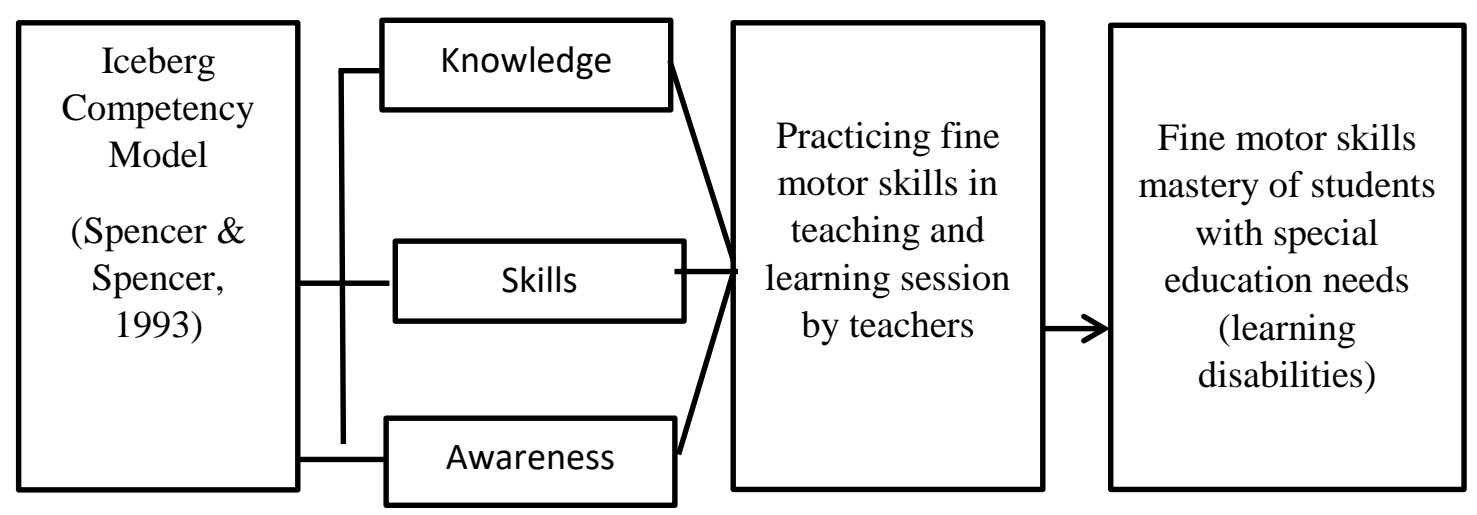

Figure 1: The research's Conceptual Framework

\section{Conclusion and Discussion}

The research's conceptual framework depicts the overall overview of this research. The conceptual framework is developed based on Iceberg Competency Model by Spencer \& Spencer (1993) which has two components - the first being visible competency that consists of knowledge and skills. The knowledge aspect that is observed in this study is to gauge the level of teachers' knowledge in fine motor skills and the relationship between the said knowledge and professional credentials. For example, the knowledge of fine motor skill is imperative to achieve teaching and learning objective. In skills aspect, the researcher will observe the teachers' ability in teaching fine motor skill and the relationship between the skills and classroom teaching experience.

The second component of the Iceberg Competency Model is hidden competency, of which for the purpose of this study, the item observed item is awareness. It is in the researcher's opinion that selfattribute and behaviour will generate awareness due to a person's faith and how the person sees one's self. It is therefore; a sense of self-awareness to be responsible and to self-improve are developed, and 
eventually will lead to the development of either positive or negative behaviour. The awareness aspect observed in this study is the level of awareness towards the importance of fine motor skill and the relationship between level of awareness with and without attending formal courses regarding fine motor skills.

Based on the Iceberg Competency Model, there are three variables identified that would influence the practice of fine motor skills in teaching and learning, which are teachers' knowledge and teaching skills as well as teachers' awareness. Evaluation on all three variables will identify the level of practice of fine motor skill among teachers that leads to the level of fine motor skill mastery among students with special education needs (learning disabilities).

\section{Corresponding Author}

Farizan binti Che Musa

Department of Special Education

Faculty of Human Development

Universiti Pendidikan Sultan Idris

Perak Malaysia.

Email: izan_fcm@yahoo.com

\section{References}

Jamian, A. R. (2011). Permasalahan Kemahiran Membaca Dan Menulis Bahasa Melayu MuridMurid Sekolah Rendah Di Luar Bandar. Jurnal Pendidikan Bahasa Melayu.1 (1): 1-12.

Azizinezhad, M., Hashemi, M., \& Darvishi, S. (2013). Relationship between EFL teachers' attitudes, teaching techniques and classroom (large and small). Procedia - Social and Behavioral Sciences 93, $134-137$

Barnaa, I., Dobrota, C., \& Draguc, M. (2013). Optimising Special Education: Active Language and Psychomotor Education. Procedia - Social and Behavioral Sciences 84, 390 - 395

Geeraerts, K., Vanhoof, J., \& Bossche, P. V. (2016). Teachers' perceptions of intergenerational knowledge flows. Teaching and Teacher Education 56, 150-161.

Grosemans, I., Boon, A., Verclairen, C., Dochy, F., \& Kyndt, E. (2015). Informal Learning Of Primary School Teachers: Considering The Role Of Teaching Experience And School Culture. Teaching and Teacher Education 47, 151-161.

Hedgcock, J. S., \& Lee, H. (2017). An exploratory study of academic literacy socialization: Building genre awareness in a teacher education program. Journal of English for Academic Purposes. 26, 17-28.

Higashionna, T., Iwanaga, R., Tokunaga, A., Nakai, A., Tanaka, K., Nakane, H., \& Tanaka, G. (2017). Relationship between motor coordination, cognitive abilities, and academic achievement in Japanese children with neurodevelopmental disorders. Hong Kong Journal of Occupational Therapy 30, 49-55.

Katkat, D. (2014). The leardership abilities of the teachers. Procedia - Social and Behavioral Sciences 116, 3880-3885. 
Kim, H., Carlson A. G., Curby, T. W., \& Winsler, A. (2016). Relations among motor,social,and cognitive skills in pre-kindergarten children with developmental disabilities. Research in Developmental Disabilities 53-54, 43-60.

Lim, C. Y., Yasin, M. H. M., \& Tahar, M. M. (2012). Genggaman Pensel Kanak-Kanak Bermasalah Pembelajaran Dalam Meningkatkan Kemahiran Menulis. Jurnal Pendidikan Bahasa Melayu. 2 (1): 65-77.

Munthe, E., \& Rogne, M. (2015). Research Based Teacher Education. Teaching and Teacher Education, 46, 17-24.

Persico, D., Milligan C., \& Littlejohn, A. (2015). The Interplay between Self-Regulated Professional Learning and Teachers' Work-Practice. Procedia - Social and Behavioral Sciences. 191, 2481-2486.

Pieters, S., Desoete, A., Roeyers, H., Vanderswalmen, R., \& Waelvelde, H. V. (2012). Behind Mathematical Learning Disabilities: What About Visual Perception And Motor Skills? Learning and Individual Differences. 22, 498 - 504.

Reimer, A. M., Cox, R. F. A., Boonstra, F. N., Sanden, D. M. W. G. N. (2015). Measurement of FineMotor Skills in Young Children with Visual Impairment. Journal of Developmental and Physical Disabilities.

Shohani, S., Azizifar, A., Gowhary, H., \& Jamalinesari, A. (2015). The Relationship between Novice and Experienced Teachers' Self- Efficacy for Personal Teaching and External Influences. Procedia - Social and Behavioral Sciences 185, 446- 452.

Gomez, S. E., Nunez, S. M. J., Gomez, P. A. I., \& Trapero, P. N. (2015), Lesson study and the development of teacher's competences. International Journal for Lesson and Learning Studies. 4, $209-223$.

Spencer, L. M. J., \& Spencer, S. M. (1993). Competence At Work, Models For Superior Performance. New York: John Wiley \& Sons, Inc.

Terziev, V. (2014). Analysis of Educational Needs Assessment Methodology of Children with Special Educational Needs in Bulgaria. Procedia - Social and Behavioral Sciences 146, 47 54. 